\title{
PEMBENTUKAN IDENTITAS HIBRID TOKOH IMIGRAN DALAM ROMAN LANDNAHME KARYA CHRISTOPH HEIN
}

\author{
Wedar Pahala Lingga \\ Fakultas Ilmu Budaya, Universitas Padjadjaran, \\ wedarpahalalingga@yahoo.com \\ N. Rinaju Purnomowulan \\ Fakultas Ilmu Budaya, Universitas Padjadjaran, \\ n.r..purnomowulan@unpad.ac.id \\ Muhamad Adji \\ Fakultas Ilmu Budaya, Universitas Padjadjaran, \\ m.adji@unpad.ac.id
}

\begin{abstract}
Abstrak
Artikel ini berjudul "Pembentukan Identitas Hibrid Tokoh Imigran dalam Roman Landnahme Karya Christoph Hein". Artikel ini bertujuan untuk mengemukakan pembentukan identitas hibrid tokoh imigran dalam Roman Landnahme Karya Christoph Hein. Metode yang digunakan dalam penelitian ini adalah metode kualitatif dan deskriptif. Penelitian ini menggunakan teori hibriditas Bhabha (1994) dan integrasi imigran Heckmann (2015). Hasil dari penelitian ini adalah (1) tokoh mengalami pe-liyanan karena ia seorang imigran, (2) adaptasi tokoh dengan budaya Jerman yakni melalui pengaitan diri dengan masa lalu dan peniruan budaya lain, dan (3) identitas hibrid yang dimanifestasikan tokoh yakni menggunakan dialek campuran dalam berkomunikasi. Penelitian ini membuktikan bahwa identitas adalah konsep yang cair.
\end{abstract}

Kata kunci: identitas hibrid, konsep cair, Landnahme, tokoh imigran

\begin{abstract}
This article is entitled "The Formation of Hybrid Identity of Immigrant Character in Landnahme by Christoph Hein". The aims of this reseach is to reveal the formation of hybrid identity of immigrant character in Landnahme by Christoph Hein. This research uses qualitative and descriptive analytics methods. This research applies Bhabha's (1994) hybridity theory dan Heckmann (2015) Immigrant integration theory. The result of this research are (1) the main character is viewed as Others because he is an immigrant, (2) the adaptation process of the main character with German cultures is performed by presenting the past memories of the main character in his present lives and imitating other culture, (3) the hybrid identity manifested by the main character by using mixed dialects in his daily conversation. This research proofs identity is a fluid concept.
\end{abstract}

Keywords: fluid concept, hybrid identity, immigrant character, Landnahme

\section{PENDAHULUAN}

Penelitian ini membahas pembentukan identitas hibrid tokoh imigran dalam roman Landnahme karya Christoph Hein. Landnahme merupakan roman polifonik berbahasa Jerman. Konsep polifonik diperkenalkan oleh Mikhail 
Bakhtin. Dalam konsep polifonik, pengarang dapat memasukkan perspektif yang bersifat kontradiktif melalui tokoh-tokohnya (Bakhtin, 1984). Roman ini disajikan melalui lima perspektif cerita yang diwakili oleh tokoh Thomas Nicolas, Marion Demutz, Peter Koller, Katharina Hollenbach, dan Sigurd Kitzkerow. Setiap tokoh menceritakan fase hidup yang berbeda-beda dari tokoh utama Bernhard Haber. Landnahme diterbitkan pada tahun 2004 oleh penerbit Suhrkamp. Roman ini memperoleh banyak pujian dari para kritikus sastra di Jerman, dan memperoleh penghargaan dari Schiller-Gedächtnispreis pada tahun 2004. Roman ini dipilih sebagai objek penelitian karena menampilkan permasalahan identitas imigran etnis Jerman.

Dalam studi poskolonial, identitas hibrid dipahami sebagai identitas baru yang diperoleh melalui percampuran budaya, tanpa melihat salah satu budaya sebagai yang eksotis. Dalam bukunya yang berjudul The Location of Culture, Homi Bhabha (1994) berpendapat bahwa identitas hibrid dapat diperoleh dengan cara mimicry, atau peniruan, terhadap budaya dominan. Landnahme berkisah mengenai kehidupan seorang imigran etnis Jerman bernama Bernhard Haber, ia datang ke Jerman usai Perang Dunia II dari kota Breslau, kini bernama Wroclaw, Polandia. Bhabha (1994) berargumentasi bahwa subjek yang berada di liminal budaya yang saling bertemu akan mengalami disorientasi dan keterasingan. Bernhard mengalami disorientasi budaya, ia membawa budaya JermanPolandia, dan harus beradaptasi dengan budaya Jerman baru. Hal tersebut membuatnya mengalami keterasingan dan kebingungan mengenai identitas dirinya.

Etnis Jerman merupakan etnis yang tersebar mulai dari wilayah Eropa Tengah, Eropa Timur, hingga Asia Tengah. Usai Perang Dunia II hingga periode 1960-an, sebanyak tigabelas juta etnis Jerman melarikan diri atau terusir dari wilayah bekas jajahan Jerman secara bertahap masuk ke Jerman. Sekitar sepertiga dari total imigran masuk ke wilayah Jerman Timur. Sebagian besar imigran telah kehilangan harta dan hak-haknya di tempat asalnya. Pemerintah Jerman Timur memberlakukan aturan bagi setiap warganya untuk berbagi tempat dengan para imigran, yakni dengan menyediakan satu atau dua ruangan di rumah mereka bagi para imigran. Sebagian besar imigran berlatar belakang petani dan pekerja kasar, sehingga sulit bagi mereka untuk memperoleh pekerjaan di bidang lain karena mereka tidak memiliki keahlian lain. Keberadaan para imigran dianggap sebagai benalu, mereka distereotipisasi tanpa keahlian, bodoh, pemalas, dan tidak memiliki sopan santun. Jumlah imigran yang cukup banyak menimbulkan kekhawatiran bagi penduduk Jerman. Mereka khawatir para imigran akan merebut lapangan kerja mereka dan memperburuk kondisi ekonomi Jerman yang belum pulih pasca Perang Dunia II.

Di lingkungan sekolah, Bernhard dipaksa untuk mengakui bahwa dirinya adalah seorang imigran dari Polandia. Kesan tidak menyenangkan yang diterima membuatnya menjadi tertutup. Perlakuan yang ia terima sangat membekas dan menghantui dirinya sepanjang hidup. Menurut Bhabha (1994) seseorang yang mengalami pengalaman tidak menyenangkan akan menyebabkan ambivalensi yang traumatis. Bernhard selalu mengingat bahwa kehidupannya dahulu di kota Breslau lebih menyenangkan bila dibandingkan 
dengan kehidupannya saat ini. Namun, ia juga menyadari bahwa kehidupannya yang dahulu juga tidak akan lagi bisa diperolehnya, apabila ia tetap tinggal di kota Breslau. Sikap yang ditunjukkan oleh Bernhard menunjukkan adanya ambivalensi. Bhabha (1994) berargumen bahwa ambivalen merupakan perasaan antara menginginkan atau menolaknya secara terus-menerus. Di satu sisi, ia ingin memperoleh hak sebagai warga negara Jerman karena ia merupakan etnis Jerman. Namun, di sisi lain, ia sangat tertutup dan lambat dalam beradaptasi dengan budaya Jerman.

Sikap ambivalen juga ditunjukkan oleh masyarakat dan pemerintah Jerman. Dalam pandangan Bhabha (1994) sikap ambivalen tidak hanya ditunjukkan oleh Liyan, tetapi juga oleh Diri. Masyarakat Jerman mengakui asas jus sanguinis, sehingga pemerintah Jerman membuka pintu untuk menerima etnis Jerman yang berada di luar Jerman. Namun, di sisi lain, masyarakat Jerman menolak keberadaan etnis Jerman yang telah masuk ke Jerman, dan pemerintah Jerman mengeluarkan peraturan mengenai orang asing dan imigran etnis Jerman termasuk di dalamnya. Menurut badan statistik pemerintah Jerman Statistiches Bundesamt, via Heckmann (2015), orang dengan latar belakang imigran adalah semua imigran yang masuk ke Jerman setelah tahun 1949, semua imigran yang lahir di Jerman, orang Jerman dengan salah satu orangtua berlatar imigran, dan atau etnis Jerman yang bermigrasi ke Jerman setelah tahun 1949. Hal tersebut menegaskan bahwa sikap ambivalen juga ditunjukkan oleh kelompok dominan.

Dalam kesusasteraan Jerman permasalahan identitas imigran juga banyak terrepresentasi dalam karya sastra. Beberapa pengarang berlatar belakang imigran menuliskan kisah tersebut, di antaranya Abbas Khider dan Emine Sevgi Özdamar. Abbas Khider merupakan seorang imigran pencari suaka asal Irak. Ia sudah menetap di Jerman sejak pertengahan tahun 1990-an. Romannya yang berjudul Die Ohrfeige (Tamparan) berkisah mengenai pencarian identitas seorang pencari suaka di Jerman. Selanjutnya, Emine Sevgi Özdamar merupakan seorang imigran kelahiran Turki. Ia datang ke Jerman sebagai pekerja tamu dan sudah menetap sejak tahun 1965. Ia menulis trilogi roman yang berjudul Istanbul-Berlin: Sonne auf halbem Weg (Istanbul-Berlin: Matahari Setengah Jalan). Roman tersebut berkisah mengenai kehidupan dan pencarian identitas pekerja migran di Berlin.

Dalam penelitian ini digunakan tiga penelitian terdahulu yang berkaitan dengan objek roman Landnahme, tema identitas imigran, dan teori hibriditas Penelitian pertama dari Maria Fabritius yang berjudul Die kulturelle Identität italienischer Migranten in Franco Biondis Passavantis Rückkehr, Abschied der zerschellten Jahre und Lisa Mazzi-Spiegelbergs Der Kern und die Schale (Identitas Budaya Imigran Italia dalam Novel Passavantis Rückkehr dan Abschied der zerschellten Jahre Karya Franco Biondi dan Der Kern und die Schale Karya Lisa Mazzi-Spiegelberg). Penelitian ini merupakan tesis di jurusan Bahasa, Budaya, dan Penerjemahan Jerman, Universitas Tampere, Swedia. Penelitian ini dipublikasikan pada tahun 2013. Hasil dari penelitian ini adalah para tokoh imigran tidak berhasil melakukan integrasi dengan penduduk Jerman. Baik generasi pertama maupun generasi kedua sama-sama gagal melakukan integrasi. Faktor-faktor pendukung seperti kemampuan bahasa, usia, jenis 
kelamin, pengetahuan budaya, dan keterampilan kerja tidak mampu membantu dalam berintegrasi. Kegagalan berintegrasi juga disebabkan masyarakat Jerman pada periode 1970-an dan 1980-an dianggap belum bisa menjadi masyarakat yang multikultural. Penelitian ini membantu pemahaman mengenai integrasi imigran di Jerman dan teori hibriditas. Dalam penelitian ini teori hibriditas digunakan untuk melihat adaptasi para tokoh dengan budaya Jerman.

Penelitian kedua dari Anna Stoklaskova yang berjudul Christoph Hein und Reinhard Jirgl: Ein Thema - Zwei Autoren, Die Analyse von "Landnahme" und "Die Unvollendeten" (Christoph Hein dan Reinhard Jirgl: Satu Tema - Dua Pengarang, Analisis Roman "Landnahme" dan "Die Unvollendeten"). Penelitian ini merupakan tesis di jurusan Bahasa Jerman, Nordik, dan Belanda, Universitas Masarykova, Republik Ceko. Penelitian ini diterbitkan pada tahun 2011. Hasil dari penelitian ini adalah kedua roman tersebut memiliki beberapa motif yang sama, seperti rasa bersalah, trauma, kehilangan rumah, keterasinga pencarian identitas, dan kehidupan baru. Kemiripan motif dalam kedua karya sastra tersebut karena penggunaan latar tempat dan waktu yang sama, yakni di periode pemerintahan Jerman Timur. Penelitian ini menggunakan objek penelitian yang sama dengan penelitian saya yakni roman Landnahme. Penelitian ini mengungkapkan aspek historis yang melatarbelakangi penciptaan kedua karya sastra tersebut. Kontribusi dari penelitian ini membantu memahami integrasi imigran di Jerman.

Penelitian ketiga dari Uta Husfeld. Penelitian tersebut berjudul "Mehr Freiheit zur Wahrheit" Die Darstellung der sozioökonomischen und politischen Verhältnisse in der Prosa von Christoph Hein ("Lebih Banyak Kebebasan untuk Kebenaran" Representasi Kondisi Sosial-Ekonomi dan Politik dalam Prosa Karya Christoph Hein). Penelitian ini merupakan tesis di Institut Teknologi Waterford, Irlandia. Penelitian ini diterbitkan pada tahun 2009. Hasil dari penelitian ini menunjukkan bahwa dalam karya-karya Hein ditemukan adanya keberlanjutan perubahan kondisi sosial-ekonomi dan politik. Setiap karyanya mewakili keadaan sosial-ekomoni dan politik pada masanya. Penelitian ini membahas peran negara dalam permasalahan integrasi imigran. Dalam analisisnya terhadap roman Landnahme, Husfeld menemukan bahwa negara menunjukkan ambivalensi dalam penanganan terhadap imigran etnis Jerman. Penelitian ini menggunakan korpus yang sama dengan penelitian saya yakni roman Landnahme. Kontribusi dalam penelitian ini adalah membantu memahami permasalahan integrasi imigran di Jerman.

Berdasarkan latar belakang mengenai permasalahan identitas imigran etnis Jerman yang tertuang dalam roman Landnahme, maka tujuan yang ingin dicapai dalam penelitian ini adalah untuk mengemukakan pembentukan identitas hibrid tokoh imigran dalam roman Landnahme karya Christoph Hein.

\section{METODE PENELITIAN}

Dalam penelitian ini digunakan metode kualitatif dengan analisis deskriptif. Pengumpulan data kepustakaan didapat dari berbagai sumber referensi yang relevan. Objek yang digunakan adalah roman Landnahme karya Christoph Hein. Setelah berbagai data diperoleh, langkah selanjutnya adalah melakukan analisis untuk mengungkapkan pembentukan identitas hibrid tokoh 
imigran ditampilkan dalam roman Landnahme. Adapun tahapan penelitian adalah sebagai berikut. Pertama, melakukan pembacaan intentif terhadap objek penelitian untuk menemukan permasalahan identitas yang dihadapi tokoh migran. Kedua, melihat penggambaran tokoh imigran dalam menghadapi permasalahan identitasnya, bagaimana ia memosisikan diri, dan upaya dalam membentuk identitas. Ketiga, melakukan analisis kutipan teks objek penelitian yang menampilkan penggambaran pembentukan identitas hibrid tokoh imigran. Keempat, mengambil kesimpulan dan menyusun laporan penelitian. Untuk mengungkap lebih dalam mengenai pembentukan identitas hibrid tokoh imigran, artikel ini mengacu pada teori hibriditas dari Homi Bhabha (1994) yang memandang bahwa identitas hibrid dapat diperoleh melalui percampuran budaya. Selain itu, juga digunakan teori integrasi imigran Heckmann (2015) untuk melihat tahapan yang dilalui oleh tokoh imigran dalam pembentukan identitasnya.

Dalam studi poskolonial, hibriditas merupakan istilah yang mengacu pada bentuk-bentuk interaksi antarbudaya yang berbeda, dan hasil dari interaksi tersebut adalah budaya dan identitas baru. Menurut Barker (2004) identitas merupakan sesuatu yang diciptakan dan merupakan suatu proses menjadi, identitas sepenuhnya berkaitan dengan budaya. Argumen serupa dengan Barker juga dikemukakan oleh Stuart Hall (1990), menurutnya identitas budaya merupakan sesuatu yang selalu dibangun dan identitas tersebut dijadikan sebagai ciri suatu kelompok. Proses pembentukan identitas merupakan proses yang penting karena akan memengaruhi kehidupan seorang individu. Proses pencarian identitas membantu seseorang untuk membangun diri yang stabil dan koheren (Hall, 1990). Artinya, identitas merupakan suatu proses menjadi, yaitu dilakukan oleh individu agar dirinya dapat diidentifikasikan sebagai bagian dari kelompok tertentu.

Tulisan Hall (1990) yang berjudul Cultural Identity and Diaspora mengemukakan dua konsep identitas, yakni konsep esensialisme dan antiesensialisme. Pertama, konsep esensialisme memandang bahwa identitas merupakan sesuatu yang tunggal, terberi, dan ajeg (Hall, 1990). Dalam konsep ini oposisi biner terbentuk karena tidak diakuinya perbedaan. Struktur oposisi biner tersebut diwakilkan oleh Diri dan Liyan, penjajah dan terjajah, subjek dan objek. Kaum penjajah menjadikan struktur tersebut sebagai pedoman untuk menempatkan posisinya di masyarakat sebagai subjek dan kaum terjajah sebagai objek. Kedua, konsep anti-esensialisme menentang pandangan yang ada dalam konsep esensialisme. Konsep anti-esensialisme memandang bahwa identitas merupakan konstruksi yang diwacanakan lewat bahasa (Hall, 1990). Dalam antiesensialisme identitas diciptakan sebagai praktik pemaknaan melalui bahasa. Pemaknaan tersebut tidak bisa lepas dari kepentingan pihak-pihak tertentu. Konsep ini mengakui adanya subjektivitas diri yang terbentuk dari berbagai perbedaan. Argumen serupa dikemukakan oleh Barker (2004), menurutnya Diri merupakan subjek yang secara terus-menerus mengalami pembentukan. Hal tersebut membuat Diri mengalami ketergantungan hubungan yang timbal-balik dengan Liyan, sehingga perbedaan antara Diri dan Liyan menjadi samar adanya. 
Argumen yang serupa dengan Hall juga diungkapkan oleh Homi Bhabha. Dalam buku yang berjudul The Location of Culture, Bhabha mengemukakan teori hibriditas yang menentang adanya konsep oposisi biner Diri dan Liyan. Konsep oposisi biner dibuat untuk memberi jarak atau memisahkan Diri dengan Liyan. Menurut Bhabha (1994) hibriditas atau percampuran budaya merupakan salah satu bentuk perlawanan kaum terjajah terhadap kaum penjajah. Bhabha meyakini bahwa budaya tidak bisa dipisah-pisah. Menurutnya, garis pemisah antara dua kebudayaan tidak pernah ajeg, dan tidak dapat diketahui batas serta ujungnya (Bhabha, 1994). Dalam konsep hibriditas, kebudayaan lain tidak dipandang sebagai sesuatu yang eksotis. Bhabha (1994) berargumen bahwa terjadinya percampuran budaya berada di ruang liminalitas atau ruang ketiga, yakni di antara Diri dan Liyan. Lebih lanjut, ia mengibaratkan liminalitas seperti sebuah anak tangga pada sebuah rumah yang dapat menghubungkan antara lantai bawah dengan lantai atas. Bhabha (1994) meyakini bahwa identitas merupakan bentuk yang dinamis dan cair. Menurutnya, identitas tidak bersifat ajeg dan stabil, melainkan selalu terbuka terhadap berbagai bentuk pemaknaan baru (Bhabha, 1990). Pendapat Bhabha senada dengan pendapat Hall. Menurut Hall (1990) identitas merupakan sebuah proses menjadi. Sehingga, keberadaan ruang ketiga tersebut menunjukkan adanya interaksi simbolik antara dua budaya. Interaksi tersebut berupa penerimaan dan pertukaran budaya yang dialogis. Dalam ruang ketiga terdapat ruang yang luas untuk resistensi. Artinya, mimikri yang dilakukan kaum terjajah tidak selalu berarti sebagai sebuah bentuk kepatuhan terhadap kaum penjajah.

Dalam sebuah budaya hibrid terdapat proses yang disebut mimikri, atau peniruan. Proses mimikri merupakan bentuk perlawanan kaum terjajah terhadap kaum penjajah melalui percampuran budaya. Menurut Bhabha (1994) dalam konsep mimikri juga terdapat unsur mengejek, atau mockery. Hal tersebut karena kaum terjajah tidak melakukan peniruan secara utuh, atau Bhabha (1994) menyebutnya "almost the same, but not quite". Tindakan mimikri secara tidak sadar dibangun oleh kaum terjajah untuk menyamai kaum penjajah. Kaum terjajah membangun pola pikir, perilaku, semangat, dan gaya hidup baru yang menjadikannya sebagai sebuah identitas baru. Selama proses pembentukan identitas baru tersebut akan ditemukan berbagai hal yang saling bertentangan. Tindakan mimikri menghasilkan efek yang ambigu dan kontradiktif, baik bagi penjajah maupun terjajah. Sifat ambigu yang muncul oleh Bhabha disebut sebagai ambivalensi. Menurut Bhabha (1994) ambivalensi merupakan fluktuasi secara terus-menerus antara menginginkan dan menolaknya, atau dapat disebut sebagai hakikat yang tidak stabil, tidak identik, dan berlawanan. Efek dari proses mimikri terasa dalam dan mengganggu. Hal tersebut menimbulkan kebingungan bagi kaum terjajah dalam proses mereka keluar dari posisi terjajah menuju ke posisi beradab. Ambivalensi menyebabkan mimikri kaum terjajah menjadi tidak penuh karena ambiguitas wacana kolonial. Konstruksi kolonial memperoleh pemaknaan yang bermacam-macam, atau bahkan bertentangan.

Untuk menyokong teori identitas hibrid Bhabha digunakan teori intengasi imigran yang diargumentasikan oleh Friedrich Heckmann. Dalam bukunya yang berjudul Integration von Migranten: Einwanderung und neue Nationbildung, Heckmann (2015) berargumen bahwa proses integrasi merupakan kebutuhan 
fungsional bagi individu dalam suatu sistem sosial. Lebih lanjut, ia mengemukakan bahwa proses integrasi berhubungan dengan mengamankan dan memperkuat hubungan dalam sistem sosial tertentu, atau untuk mengintegrasikan anggota baru ke dalam sistem sosial (Heckmann, 2015). Artinya, Integrasi yang sukses akan mempermudah individu dalam memperbaiki kondisi kehidupan. Menurut Heckmann (2015), mengutip argumentasi Esser, terdapat empat tahap dasar dalam sebuah proses integrasi, yakni Kulturation (pemahaman budaya), Platzierung (penempatan), Interaktion (interaksi), dan Identifikation (identifikasi). Keempat proses dasar ini akan sangat menentukan tingkat keberhasilan integrasi seorang individu ke dalam masyarakat.

Tahap pertama ialah Kulturation atau pemahaman budaya. Pada tahap awal ini kemampuan seseorang berupa kompetensi dan pengetahuan tertentu mengenai negara tujuan migrasi sangat diperlukan untuk dapat berinteraksi dengan masyarakatnya. Kemampuan ini merupakan prasyarat awal bagi individu dalam setiap proses integrasi. Jika seseorang tidak menguasai kompetensi atau pengetahuan tertentu yang diperlukan untuk berhubungan dengan sistem sosial baru, maka ia akan memperoleh penolakan atau pengasingan. Semakin lama proses penyerapan kompetensi dan pengetahuan mengenai negara tujuan migrasi, akan semakin mempersulit proses interaksi dengan sistem sosial masyarakatnya. Kendala yang sering ditemui dalam tahap awal ini adalah kemampuan penguasaan bahasa dan budaya negara tujuan migrasi.

Tahap kedua adalah Platzierung atau penempatan. Pada tahap ini seseorang akan memperoleh posisi sosial tertentu. Kompetensi dan pengetahuan tertentu yang dimiliki akan membawa seseorang pada posisi sosial tertentu di negara tujuan migrasi. Posisi sosial tersebut akan memengaruhi perolehan hakhak tertentu, seperti hak kewarganegaraan, pekerjaan, pendidikan, dan berbagai jaminan sosial lainnya. Menurut Esser, sebagaimana dikutip oleh Heckmann (2015), langkah dalam tahap ini bertujuan untuk melawan dan meminimalisasi berbagai bentuk diskriminasi yang akan diterima. Artinya, dengan memiliki posisi sosial tertentu, seseorang dapat meminimalisasi berbagai bentuk diskriminasi yang akan diperolehnya.

Tahap ketiga yakni Interaktion atau interaksi. Tahap ini merupakan kasus khusus dalam aksi sosial. Dengan bermodalkan kompetensi dan pengetahuan tertentu seseorang dapat menyelaraskan diri dan membentuk hubungan dengan masyarakat di suatu sistem sosial baru. Dalam proses ini, peristiwa-peristiwa emosional dapat menghambat proses integrasi. Contohnya kecemasan atau ketakutan untuk berinteraksi dengan orang tidak dikenal akan menyebabkan kesulitan bagi dirinya dalam bermasyarakat. Tahap ini menekankan bahwa integrasi tidak dapat dilakukan apabila tidak ada interaksi dengan masyarakat setempat. Misalnya, sebuah komunitas imigran tinggal dalam satu wilayah terpadu dan dapat memenuhi semua kebutuhan hidup sehari-hari. Hal tersebut akan membuat anggota komunitas tidak perlu meninggalkan zona nyamannya untuk beinteraksi dengan masyarakat setempat sehingga integrasi dengan masyarakat setempat tidak pernah berhasil. 
Tahap keempat adalah Identifikation atau identifikasi. Tahap akhir ini merupakan proses integrasi yang lebih bersifat abstrak. Pada tahap akhir ini seseorang akan merasa memiliki dan terikat dengan suatu sistem sosial baru. Namun, rasa memiliki dan terikatnya hanya didasari oleh tingkat kepentingannya, karena tujuan dari proses ini adalah untuk memastikan bahwa ia diterima dalam suatu sistem sosial baru.

\section{HASIL DAN PEMBAHASAN}

Roman Landnahme berkisah mengenai kehidupan seorang imigran etnis Jerman asal Polandia bernama Bernhard Haber yang mulai tinggal di kota Guldenberg, Jerman Timur, sejak tahun 1950. Dalam roman tersebut ditemukan adanya permasalahan identitas dan keterasingan yang dialami oleh tokoh utama. Untuk menganalisis permasalahan tersebut, dalam penelitian ini analisis akan dibagi menjadi tiga subbab. Subbab pertama memaparakan latar belakang tokoh imigran. Subbab kedua memaparkan adaptasi tokoh imigran dengan budaya Jerman. Subbab ketiga memaparkan identitas hibrid yang dimanifestasikan oleh tokoh imigran.

\subsection{Latar Belakang Tokoh Imigran}

Pada subbab ini akan dipaparkan mengenai latar belakang tokoh imigran. Latar belakang budaya imigran akan sangat memengaruhi proses adaptasi dengan budaya negara tujuan migrasi. Semakin banyak kemiripan antara budaya yang dianut dengan budaya negara tujuan migrasi akan semakin mempermudah proses adaptasi, sehingga permasalahan perbedaan budaya seperti bahasa, gaya hidup, makanan, dan agama akan lebih mudah untuk diatasi. Friedrich Heckmann dalam bukunya yang berjudul Integration von Migranten: Einwanderung und Neue Nationenbildung memaparkan empat tahap integrasi imigran. Tahap pertama yakni tahap Kulturation atau pemahaman budaya. Menurut Heckmann (2015) pada tahap awal ini kemampuan seseorang berupa kompetensi dan pengetahuan tertentu mengenai negara tujuan migrasi sangat diperlukan untuk dapat berinteraksi dengan masyarakatnya. Sebelum pindah ke Jerman, Bernhard merupakan seorang etnis Jerman yang tinggal di kota Breslau. Kota tersebut dahulu merupakan wilayah jajahan Jerman. Usai Perang Dunia II kota tersebut menjadi bagian dari negara Polandia dan berganti nama menjadi Wroclaw. Letak kota yang tidak jauh dari batas wilayah Jerman modern, membuat pengaruh bahasa dan budaya Jerman masih tertanam kuat pada diri Bernhard. Hal tersebut menunjukkan bahwa seharusnya Bernhard akan lebih mudah untuk beradaptasi dengan budaya Jerman. Hal tersebut ditunjukkan dalam kutipan berikut.

"Er kommt aus Polen und konnte in den letzten Jahren nur unregelmäßig eine Schule besuchen."

[...]

Ein Polacke", sagte ein Junge aus einer der hinteren Reihen halblaut.

$[\ldots]$ 
Das war sehr hässlich", sagte Fräulein Nietzscke, "und ich will dieses dumme Wort nie wieder hören. Nie wieder! Habt ihr verstanden? Und Bernhard ist kein Pole, er ist ein Deutscher genauso wie ihr."

"Dia berasal dari Polandia, dan beberapa tahun terakhir ini dia jarang bersekolah." $[\ldots]$

"Orang Polandia", kata seorang anak lelaki dari salah satu barisan belakang dengan suara lirih.

$[\ldots]$

"Itu perkataan yang buruk", kata nona Nietzscke, "Dan aku tidak ingin mendengar perkataan buruk seperti itu lagi. Jangan pernah katakan lagi! Apakah kalian paham? Dan Bernhard bukanlah orang Polandia, dia orang Jerman sama seperti kalian."

(Hein, 2004:17)

Dari kutipan di atas didapatkan bahwa kehidupan Bernhard selama masa perang dan pasca perang tidak menentu. Pembelaan diberikan oleh nona Nietzscke merupakan bentuk keyakinan bahwa Bernhard tidak berbeda dari masyarakat Jerman pada umumnya. Penegasannya bahwa Bernhard bukanlah orang Polandia merupakan bentuk dukungan moril kepada Bernhard bahwa ia merupakan penduduk Jerman yang sah, dan bukan seorang imigran. Ucapan salah seorang murid yang menyebut Bernhard sebagai ein Polacke-orang Polandia- merupakan bentuk dari pemahaman baru penduduk Jerman terhadap status kewarganegaraan Jerman. Menurut badan statistik pemerintah Jerman Statistiches Bundesamt, via Heckmann (2015), orang dengan latar belakang imigran adalah semua imigran yang masuk ke Jerman setelah tahun 1949, semua imigran yang lahir di Jerman, orang Jerman dengan salah satu orang tua berlatar imigran, dan atau etnis Jerman yang bermigrasi ke Jerman setelah tahun 1949. Aturan tersebut menegaskan bahwa Bernhard merupakan imigran asal Polandia, yang artinya ia juga membawa serta budaya Polandia. Aturan tersebut berlawanan dengan gagasan yang dianut penduduk Jerman sejak abad ke-18 hingga Perang Dunia II. Sebelum ada aturan tersebut, penduduk Jerman mengusung gagasan Jerman yang homogen, yakni semua individu yang merupakan etnis Jerman dan menetap di wilayah Jerman merupakan bagian dari negara Jerman (Brubaker, 1994). Gagasan tersebut juga bermakna bahwa hanya ada satu budaya dan bahasa yang diakui oleh Jerman, yakni budaya dan bahasa Jerman. Gagasan tersebut telah dianut sejak abad ke-18 saat Jerman masih berbentuk kekaisaran. Luas wilayah Jerman di bawah kekaisaran terbentang mulai dari Eropa Tengah hingga Eropa Timur. Kota Breslau tempat tinggal Bernhard dahulunya merupakan wilayah yang berada di bawah kekuasaan Jerman hingga Perang Dunia II.

Etnis Jerman di wilayah Eropa Timur menggunakan bahasa Jerman dalam berkomunikasi dan tiap wilayah memiliki dialek tersendiri. Bernhard berbicara dalam dialek Jerman-Silesia, dialek tersebut merupakan dialek yang digunakan di wilayah Silesia. Usai Perang Dunia II sebagian besar wilayah Silesia menjadi bagian dari Polandia, dan sebagian kecilnya menjadi bagian Jerman dan Republik Ceko. Dialek Jerman-Silesia sudah dipakai sejak abad ke-12 dan 
merupakan bagian dari dialek Jerman Tinggi (Kamusella, 2012). Dialek JermanSilesia mudah dikenali oleh penduduk Jerman karena karakter suarannya terdengar lebih serak dan berat. Berikut pemaparan teks yang menyatakan hal tersebut.

Was wir sofort begriffen hatten, war, dass er einen dieser rauhen, ostdeutschen Dialekte sprach. Alle hatten sofort mitbekommen, dass wieder ein aus Pommern oder Schlesien Vertriebener in unsere Schule gekommen war.

Yang segera kami pahami adalah bahwa ia berbicara dalam salah satu dialek Jerman wilayah timur. Semua anak segera menyadari bahwa ada pengungsi asal Pomeria atau Silesia yang masuk ke sekolah kami.

(Hein, 2004:16)

Selain dari dialek, penampilan dari para imigran juga mudah dikenali. Penampilan para imigran etnis Jerman menunjukkan bahwa kondisi di Polandia lebih buruk dari Jerman. Hal tersebut ditunjukkan dalam kutipan berikut.

Sie waren allesamt ärmlicher gekleidet als die Kinder der Einheimischen, ihre Strümpfe und Joppen waren geflickt, runde lederstücke waren nicht nur auf den Ellbogen angebracht, und vor allem ihr Schulwerk war alt und rissig.

Mereka semua berpakaian lebih buruk dari anak-anak di kota kami, stoking dan jaket mereka ditambal, potongan kulit bundar tidak hanya di siku, dan sebagian besar dari alat sekolah mereka sudah lama dan rusak.

(Hein, 2004:16)

Ketika masih berada di bawah kekuasaan Jerman, kehidupan Bernhard jauh lebih baik, ia memeroleh pakaian, makanan, dan pendidikan yang layak. Ayahnya memiliki bengkel kayu dan memiliki penghasilan yang cukup, serta mereka tinggal di rumah milik sendiri. Setelah lepas dari jajahan Jerman, Polandia jatuh ke tangan Uni Soviet. Keadaan penduduk Polandia di bawah kendali Uni Soviet tidak lebih baik daripada saat berada di bawah kendali Jerman. Kehidupan penduduknya menjadi tidak menentu, khususnya bagi etnis Jerman. Mereka mendapat tekanan untuk meninggalkan tempat tinggalnya. Sehingga banyak di antara mereka yang melarikan diri ke Jerman. Keadaan imigran etnis Jerman sangat buruk, sebagian besar dari mereka meninggalkan Polandia tanpa membawa apa-apa. Demikian pula yang terjadi pada keluarga Bernhard, mereka datang hanya dengan membawa pakaian lusuh dan perkakas kayu. Berdasarkan pemaparan mengenai bahasa dan budaya etnis Jerman di wilayah Silesia, Polandia, Bernhard memenuhi semua kualifikasi untuk disebut sebagai seorang etnis Jerman, yakni berupa kepemilikan bahasa dan budaya Jerman.

Sebagai seorang etnis Jerman, ia memiliki kesempatan untuk menjadi warga negara Jerman berdasarkan asas jus sanguinis yang dianut oleh pemerintah Jerman. Menurut Brubaker (1994) pemerintah Jerman memberikan 
naturalisasi kepada etnis Jerman dengan syarat bahwa orang tersebut telah diusir dari wilayah bekas jajahan Jerman, oleh pemerintah yang berkuasa di bekas wilayah jajahan Jerman tersebut. Bernhard termasuk imigran yang diusir dari wilayah bekas jajahan Jerman oleh pemerintah Polandia. Surat pindah keluarga Bernhard disetujui oleh pemerintah Polandia, Uni Soviet, dan Jerman Timur, sehingga mereka bisa memperoleh hak untuk dinaturalisasi oleh pemerintah Jerman Timur. Hal tersebut merupakan keuntungan bagi keluarga Bernhard, karena mereka akan memperoleh jaminan menjadi warga negara Jerman dan tidak akan terkatung-katung mengenai status kewarganegaraannya. Hal tersebut diperlihatkan melalui kutipan berikut.

Da seine Heimatstadt nach dem Krieg zu Polen gehörte, sollte er in eine deutsche Stadt der sowjetischen Zone entlassen warden.

[...]

Schließlich gab man ihm Papiere für unsere Stadt, weil laut einer Liste in Guldenberg Tischler benötig würden.

Karena setelah perang kota kelahirannya menjadi milik Polandia, ia harus pindah ke wilayah Jerman yang berada di bawah kendali Uni Soviet.

[...]

Akhirnya pemerintah Uni Soviet memberikan surat kepadanya untuk pergi ke kota kami, karena menurut daftar Guldenberg membutuhkan tukang kayu.

(Hein, 2004:22)

Dari narasi di atas, keluarga Bernhard masuk ke Jerman dengan cara yang sah. Artinya, mereka akan memperoleh hak yang setara dengan penduduk Jerman. Keadaan keluarga Bernhard selama di Breslau tidak begitu baik. Ayahnya seorang tukang kayu, ibunya seorang petani, adiknya meninggal karena kekurangan gizi, dan dirinya tidak memperoleh pendidikan formal yang layak. Secara umum keluarga Bernhard merupakan keluarga miskin, dengan tingkat pendidikan rendah, dan hanya memiliki keahlian sebagai tukang kayu dan petani. Dengan kondisi seperti itu memperjelas bahwa kepindahan keluarga Bernhard ke Jerman adalah untuk memperbaiki taraf hidup.

Keadaan keluarga Bernhard merupakan cerminan umum dari keadaan imigran etnis Jerman lainnya. Gambaran keadaan etnis Jerman di Polandia tersebut memunculkan stereotipe dari penduduk Jerman. Datang ke Jerman dalam kondisi yang tidak lebih baik dari penduduk Jerman menyebabkan mereka mengalami pe-liyan-an. Stereotipe yang melekat pada imigran etnis Jerman di antaranya pemalas, bodoh, pembuat onar, dan tidak memiliki sopan santun.

\subsection{Adaptasi Tokoh Imigran dengan Budaya Jerman}

Subbab ini memaparkan adaptasi tokoh imigran dengan budaya Jerman. Dalam setiap proses adaptasi akan selalu memunculkan permasalahan identitas. Dalam teori integrasi imigran, proses adaptasi berlangsung di tahap Platzierungpenempatan dan Interaktion-interaksi. Pada tahap Platzierung seseorang akan 
memperoleh posisi sosial tertentu. Kompetensi dan pengetahuan tertentu yang dimiliki akan membawa seseorang pada posisi sosial tertentu di negara tujuan migrasi (Heckmann, 2015). Posisi sosial yang didapat merupakan pijakan awal dalam proses adaptasi dengan lingkungan baru. Posisi sosial tersebut akan memengaruhi perolehan hak-hak tertentu, seperti hak kewarganegaraan, pekerjaan, pendidikan, dan berbagai jaminan sosial lainnya. Bernhard datang sebagai seorang pengungsi miskin, sehingga keberadaannya di kota Guldenberg dipandang sebelah mata oleh penduduk kota. Dirinya, juga imigran etnis Jerman lainnya, tidak mendapat sambutan baik dari penduduk kota. Keberadaannya dianggap sebagai benalu dan hanya menjadi beban kota. Posisi sosial yang diperoleh Bernhard adalah sebagai penduduk kelas bawah dan mengalami peliyan-an. Posisi sosial tersebut sangat memungkinkan dirinya memperoleh diskriminasi.

Setelah tahap Platzierung, seseorang akan melanjutkan ke tahap selanjutnya, yakni Interaktion atau interaksi. Tahap ini merupakan bentuk aksi sosial, seseorang dituntut agar mampu menyelaraskan diri dengan budaya setempat dan menjalin hubungan dengan masyarakatnya. Ruang interaksi Bernhard cukup luas, yakni berada di seputar kota Guldenberg. Interaksinya lebih sering dengan teman sekolah, sesama imigran etnis Jerman, dan rekan bisnis. Pada tahap tersebut akan memunculkan berbagai permasalahan yang berkenaan dengan identitas, seperti mimikri, ambivalensi, keterasingan, resistensi, dan pengaitan diri dengan masa lalu. Menurut Barker (2004) identitas merupakan sesuatu yang diciptakan dan merupakan suatu proses menjadi, identitas sepenuhnya berkaitan dengan budaya. Proses tersebut akan sangat membantu individu dalam menjalani kehidupannya di sistem sosial yang baru. Proses pencarian identitas membantu seseorang untuk membangun diri yang stabil dan koheren (Hall, 1990).

Pengaitan diri dengan masa lalu ditunjukkan oleh Bernhard. Ia datang ke Jerman sebagai seorang anak berusia 10 tahun yang tidak pandai dan memiliki kemampuan bahasa Jerman yang buruk. Di awal kedatangannya, Bernhard langsung bersikap tertutup dan hanya sedikit menunjukkan ketertarikan untuk berinteraksi dengan orang lain. Sikap tersebut masih terbawa hingga ia remaja. Interaksi yang dilakukannya hanya kepada beberapa orang. Kehidupannya yang sengsara membuatnya mencari keterhubungan antara kehidupannya saat ini dengan kehidupan masa lalunya. Caranya mengaitkan diri dengan masa lalu, yakni dengan bercerita mengenai kerinduan akan kampung halamannya kepada teman-temannya. Ia selalu memikirkan bagaimana caranya agar ia dapat kembali ke Breslau. Namun, ia juga menyadari bahwa keadaannya saat ini tidak memungkinkan dirinya untuk kembali ke Breslau. Dibutuhkan uang yang tidak sedikit hanya untuk sekadar mengunjungi kota Breslau. Bagi Bernhard, uang adalah hal yang tidak dimilikinya di tahun-tahun awal keberadaannya di Guldenberg. Salah satu tujuan Bernhard jika ia bisa kembali ke Breslau adalah mengunjungi makam kakeknya. Hal tersebut ditunjukkan dalam kutipan berikut.

Er sagte, er würde gern zu seinem Großvater gehen, der liege ein paar hundert Kilometer entfernt, und sein Grab sei für die ganze Familie nicht erreichbar. 
"Hattest du deinen Opa gern?", fragte ich ihn.

Erhat genickt, die Unterlippe vorgeschoben und gesagt: "Mein Opa war der Einzige..."

Ia berkata, ia ingin pergi mengunjungi kakeknya, jaraknya beberapa ratus kilometer jauhnya, dan makamnya tidak dapat diakses oleh seluruh keluarga.

“Apakah kau menyukai kakekmu?" Tanyaku padanya.

Dia mengangguk, memajukan bibir bawahnya dan berkata: "Kakekku adalah satu-satunya ...".

(Hein, 2004:139)

Kakek Bernhard meninggal saat Perang Dunia II. Kerinduan untuk mengunjungi makam kakeknya merupakan bentuk pengaitan diri dengan masa lalu yang dilakukan oleh Bernhard. Sosok kakeknya merupakan gambaran kehidupan masa lalunya di Breslau. Kerinduan terhadap kakeknya merupakan kerinduannya terhadap kehidupannya yang dulu. Jawaban bahwa kakeknya adalah satu-satunya yang ia sukai merupakan gambaran perasaan Bernhard yang menganggap bahwa satu-satunya kehidupan yang ia sukai adalah ketika ia masih tinggal di Breslau. Kakeknya merupakan perwujudan dari budaya Silesia dan kehidupannya yang dulu. Caranya mengaitkan dirinya dengan kakeknya merupakan cerminan bahwa ia tidak ingin kehilangan identitasnya sebagai orang Silesia. Namun, setelah ia menjadi orang kaya, ia tetap tidak pernah kembali ke Breslau walau hanya untuk sekadar berkunjung. Tindakan Bernhard tersebut merupakan caranya untuk berdamai dengan masa lalunya. Hal tersebut juga menunjukkan bahwa Guldenberg telah menjadi rumahnya.

Sebagai seorang imigran, Bernhard bukanlah sosok yang selalu berusaha menjadi penduduk yang baik. Ia hidup dengan caranya sendiri, dan jika ia melakukan sesuatu, maka hal tersebut harus menguntungkan bagi dirinya. Sebagai seorang imigran, ia distereotipisasi bodoh, pemalas, pembuat onar, dan tidak memiliki sopan santun. Stereotipe tersebut menunjukkan bahwa imigran etnis Jerman membawa budaya "Liyan", yakni budaya rendah. Di sekolah, caranya menyelaraskan diri dengan budaya Jerman adalah dengan berusaha mengikuti aturan sekolah. Berikut kutipan yang menunjukkan hal tersebut.

In jedem Schuljahr war er der führende Kandidat für das Sitzenbleiben, doch regelmäßig und Jahr für Jahr verbesserten sich in den letzten entscheidenden Wochen seine Zensuren wundersamer Weise ein wenig, so dass er mit Ach und Krach die gesetzte Hürde übersprang und ins nächste Schuljahr versetzt wurde. [...]

Da Bernhard ein sehr ruhiger Schüler war, der den Unterricht nicht störte, [...].

Di setiap tahun ajaran, ia merupakan kandidat utama untuk tinggal di kelas, namun secara mengagumkan nilainya meningkat di mingguminggu terakhir setiap tahunnya, sehingga ia dapat naik kelas.

$[\ldots]$ 
Karena Bernhard adalah anak yang pendiam, tidak menggangu proses belajar, $[\ldots]$

(Hein, 2004:27)

Seperti yang telah dijelaskan di awal paragraf, setiap hal yang dilakukan Bernhard harus menguntungkan dirinya. Narasi di atas menunjukkan bahwa satu-satunya cara menyelamatkan dirinya dari tidak naik kelas adalah dengan menjadi anak pendiam dan tidak berbuat onar. Kekurangannya dalam memahami pelajaran ia tukar dengan sikap pendiam dan tidak berbuat onar. Sikap tersebutlah yang selalu menolongnya di setiap tahun ajaran baru agar tidak tinggal di kelas. Nilai-nilai akademiknya sangat buruk, terutama dalam pelajaran bahasa Jerman dan Rusia. Bahkan guru-gurunya memprediksi ia tidak akan mempunyai masa depan. Alasan utama guru-gurunya tetap menaikkan Bernhard ke kelas selanjutnya adalah karena ia tidak mengganggu proses belajar dan tidak berbuat onar. Mimikri yang dilakukan oleh Bernhard merupakan caranya untuk memperoleh kesejajaran. Proses mimikri Bernhard berupa usaha mengikuti peraturan sekolah juga menunjukkan sisi mockery, atau ejekan. Ia melakukan peniruan yang tidak utuh, yakni dengan tidak mengikuti semua peraturan sekolah dengan baik karena ia melihat adanya ketidakkonsistenan yang ditunjukkan pihak sekolah. Syarat utama untuk naik kelas berupa nilai akademik yang mencukupi tidak perlu diraih Bernhard agar dirinya tetap bisa naik kelas. Ia hanya perlu menunjukkan diri sebagai seorang siswa yang pendiam dan tidak berbuat onar, maka ia akan diperbolehkan untuk naik kelas. Nilai yang mencukupi dapat ditukar dengan kelakuan baik sebagai syarat untuk naik kelas. Hal tersebut menunjukkan adanya sikap ambivalen dari Diri, yang diwakilkan oleh institusi sekolah. Aturan yang telah dibuat oleh pihak sekolah, dengan sendirinya dilanggar oleh pihak sekolah. Aspek kedisiplinan berupa pemenuhan berbagai syarat untuk naik kelas dengan sengaja dilanggar oleh pihak sekolah. Celah tersebut terus dimanfaatkan Bernhard hingga ia lulus sekolah. Bernhard dengan stereotipe budaya Liyan-nya, yakni seorang pemalas dan bodoh, tetap bisa melewati masa sekolah dengan "baik", tanpa perlu mengikuti semua aturan dengan baik.

\subsection{Identitas Hibrid yang Dimanifestasikan oleh Tokoh Imigran}

Subbab ketiga memaparkan identitas hibrid yang dimanifestasikan oleh tokoh imigran. Menurut Bhabha (1994) ruang tempat terjadinya percampuran budaya berada di ruang liminalitas atau ruang ketiga, yakni di antara Diri dan Liyan. Dalam teori integrasi imigran, ruang ketiga tersebut berada di dalam tahap Identifikation atau identifikasi. Tahap akhir ini merupakan proses integrasi yang lebih bersifat abstrak. Pada tahap ini seseorang akan merasa memiliki dan terikat dengan suatu sistem sosial baru (Heckmann, 2015). Keterikatan tersebut dimanifestasikan melalui identitasnya yang hibrid.

Identitas hibrid yang termanifestasikan pada diri Bernhard adalah perpaduan dialek Jerman dan Jerman-Silesia yang digunakannya dalam berkomunikasi. Menurut Kamusella (2012) dialek Jerman-Silesia memiliki lebih banyak kemiripan dengan dialek Polandia dibandingkan dengan dialek Jerman. 
Namun, sebagai wilayah yang berada di bawah kendali Jerman, bahasa Jerman merupakan bahasa utamanya. Bernhard yang lahir dan tumbuh saat Silesia masih di bawah Jerman seharusnya tidak mengalami kesulitan untuk memahami bahasa Jerman. Esser (2006) berargumen bahwa penguasaan bahasa negara tujuan migrasi sangat penting untuk memeroleh pendidikan, pekerjaan, dan membangun kontak sosial. Selama menempuh pendidikan Bernhard mengalami kesulitan dalam mempelajari bahasa Jerman. Hal tersebut membuatnya lebih sering berkomunikasi dengan sesama imigran etnis Jerman. Berikut kutipan yang menunjukkan hal tersebut.

Er vermochte nicht, sich die Vokabeln einzuprägen, zumal ihm zum Lernen daheim die Zeit fehlte und die ungewohnte, andersartige sprachliche Struktur und die ungeläufigen Zeichen ihn verwirrten und lähmten, so dass er selbst bei den einfachsten Aufgaben verzweifelt und stumm den Lehrer ansah und offensichtlich aufhörte nachzudenken und auf eine übernatürliche Eingebung hoffte.

Dia tidak bisa mengingat kosa-kata, terutama karena ia tidak memiliki waktu untuk belajar di rumah, struktur bahasa dan karakter bahasa yang tidak dikenal membingungkan dan melumpuhkannya, sehingga untuk tugas yang paling sederhana dia berhenti berpikir, hanya memandang guru dengan diam dan putus asa, dan inspirasi supernatural.

(Hein, 2004:26)

Narasi tersebut menunjukkan bahwa Bernhard memiliki kemampuan bahasa Jerman yang buruk. Namun, seiring berjalannya waktu, interaksinya dengan penduduk Guldenberg semakin membaik. Hal tersebut mengurangi intensitasnya berinteraksi dengan sesama imigran etnis Jerman. Hal tersebut dibuktikan dari kutipan berikut.

Die meisten von ihnen sprachen inzwischen unseren Dialekt, und nur gelegentlich konnte man an einem ungewöhnlichen und befremdlichen Wort ihre Llerkunft erraten oder weil sie die Rachenlaute heiserer als wir aussprachen.

Sebagian besar dari mereka sekarang berbicara dengan dialek kami, dan hanya sesekali orang bisa menebak kata asing yang mereka ucapkan atau karena mereka mengeluarkan suara yang lebih serak daripada kami.

(Hein, 2004:16)

Setelah tinggal beberapa tahun di Guldenberg, dialek Jerman-Silesia Bernhard masih belum hilang sehingga orang-orang dengan mudah dapat mengenalinya sebagai seorang imigran etnis Jerman. Namun, Bernhard tidak mempermasalahkan tanggapan orang mengenai penggunaan dialek tersebut. Menurut Bhabha (1990) identitas tidak bersifat ajeg dan stabil, melainkan selalu terbuka terhadap berbagai bentuk pemaknaan baru. Hal tersebut menunjukkan 
bahwa Bernhard menyandang identitas hibrid berupa penggunaan dialek Jerman dan Jerman-Silesia dalam komunikasinya sehari-hari.

\section{PENUTUP}

Imigran etnis Jerman dengan latar budaya Silesia mengalami pe-liyan-an oleh penduduk Jerman karena status mereka sebagai imigran. Mereka, dan juga Bernhard, distereotipisasi sebagai pemalas, bodoh, tanpa keahlian, dan tidak memiliki sopan santun. Dalam usahanya untuk keluar dari pe-liyan-an tersebut, Bernhard melakukan adaptasi dengan budaya Jerman. Adaptasi tersebut ditunjukkan dengan cara mimikri dan pengaitan diri dengan masa lalu. Mimikri yang dilakukan Bernhard berupa upaya penyelarasan diri dengan peraturan sekolah agar dirinya tidak memperoleh masalah di sekolah. Adapun pengaitan diri dengan masa lalu yang dilakukan Bernhard yakni dengan membandingkan kehidupannya di Guldenberg dengan di Breslau. Pengaitan diri tersebut membuat Bernhard dapat berdamai dengan masa lalunya. Identitas hibrid yang dimanifestasikan oleh Bernhard yakni penggunaan dialek Jerman dan JermanSilesia dalam komunikasi sehari-hari. Hal tersebut membuktikan bahwa identitas merupakan konsep yang cair.

\section{DAFTAR PUSTAKA}

Barker, Chris. 2004. Cultural Studies: Theory and Practice. London: Sage Publications.

Bhabha, Homi. 1994. The Location of Culture. London: Routledge.

Hall, Stuart. 1990. “Identity, Community, Culture, Difference." Dalam Cultural Identity and Diaspora, oleh Stuart Hall, 222-237. London: Lawrence \& Wishart.

Heckmann, Friedrich. 2015. Integration von Migranten: Einwanderung und neue Nationenbildung. Wiesbaden: Springer.

Hein, Christoph. 2004. Landnahme. Berlin: Suhrkamp.

Kamusella, Tomasz. 2012. The Silesian Language in the Early 21st Century: A Speech Community on the Rollercoaster of Politics. Fife: St. Andrew University.

Khider, Abbas. 2016. Die Ohrfeige. Munchen: Hanser.

Özdamar, Emine Sevgi. 2006. Die Istanbul-Berlin Trilogie: Sonne auf halbem Weg. Köln: Kiepenheuer \& Witsch. 